\title{
Scientific and organizational problems of breeding, genetics and biogeotechnology in animal husbandry
}

\author{
Gladiy M. ${ }^{1}$, Polupan Yu. ${ }^{2}$, Kostenko A. ${ }^{3}$, Kovtun S. ${ }^{4}$, Kuzebniy S. ${ }^{5}$, Kopylov K. ${ }^{6}$, Vysh-nevskiy
} L. ${ }^{6}$, Shcherbak O. ${ }^{8}$, Rieznykova $\mathrm{N}^{9}{ }^{9}$

${ }^{1,3}$ M. Omelyanovycha-Pavlenka str., 9, Kyjiv, 01010, Ukraine, ${ }^{2,4-9}$ M.V. Zubets Institute of Animal Breeding and Genetics, NAAS, Pohrebnjaka str., 1, Chubynske vil., Boryspil district, Kyjiv region, 08321, Ukraine; e-mail: 1,3inter.naas@gmail.com, 2,4-9irgt@online.ua

The purpose. To contour the basic achievements of domestic agrarian science and practice, to determine trends, problems and directions of the further development of pedigree cattle breeding, perspectives of scientific researches in selection, genetics and biogeotechnology of reproduction of agricultural animals. Methods. System generalization, analysis and synthesis, calculation-analytical and others. Results. Basic problems of branch are specified and ways of their solution are offered. Prime directions of development of scientific researches for maintenance of constant development of branch of milk and beef cattle husbandry in Ukraine are outlined. Reforming agriculture in modern market conditions requires development and implementation of innovative high technology highly technological development of molecular biology, genetics, biogeotechnology with the purpose to increase in volumes of production of animal production and raise its competitiveness which determines directions of implementation of state policy in sphere of animal husbandry on martempering pedigree and productive qualities of animals. One of the most actual problems is conservation of gene pool of autochthonous domestic dairy breeds. Its solution requires scientific substantiation of expediency of breeding such animals for prevention elimination of lot of genes and genic complexes which determine valuable hereditary caused qualities of animals. Conclusions. Scientific development are directed on the solution of theoretical, methodological, organizational-technological, informational-analytical problems, creation of legislative basis for implementation of modern selection-genetic methods into practice of domestic animal husbandry, realization of transition of the branch to new quality level according to European standards, modernization of system zoo-technical account, genetic research, elaboration of standardization of determination of a genotype of animals by genes of quantitative attributes, determination of the most valuable pedigree individuals for the further reproduction by parameters of optimum genetic compatibility.

Key words: cattle, breed, milk productivity, pedigree work, selection, biogeotechnology, genetics, reproduction, conservation of gene pool.

https://doi.org/10.31073/agrovisnyk201811-10

Dairy and beef cattle-breeding in our country takes up one of the leading places amongst animal-breeding sectors. Development of this sub-sector, which provides the production of complete dietary protein, demands qualified scientific support and implementation of new innovative approaches to the organization of animal breeding and selection. Modern intensive production technologies cause the development of energy- and resource-saving technologies, productivity increase, but, along with this, cause the reduction of males' and females' reproductive potential and their productive longevity.

For effective scientific provision at National Academy of Agrarian Sciences of Ukraine net the scientific-methodical centre (SMC) «Animal breeding» was created. The main institution of the Centre is M.V.Zubets Institute of Animal Breeding and Genetics of NAAS, which makes the coordination of scientific investigations on the development and realization of selection programs of the creation of new, qualitative improvement and conservation of existing farm animal breeds' 
and types' gene pool with wide use of modern achievements of genetics and biotechnology. Aim of research - to outline main achievements of native agrarian science and practice, to define tendencies, problems and directions of further breeding cattle-breeding development, prospects of scientific research in selection, genetics and biotechnology of farm animals' reproduction. Research materials and methods. Analytical investigation of dynamics of dairy cattle population and productivity was done at the base of statistical materials [14], breed composition and productivity dynamics of breeding cows of main breeds - at the base of State Breeding Register [3]. Results of investigations. During the number of years the tendency towards the reduction of dairy cattle number is saved. The highest rate of this process is marked in the controlled part of the population. Only for the last 5 years the total number of breeding cows decreased from 153.6 th. of heads to 128.2 th., so, by $12 \%$. The total milk production decreased from 11248.5 th.. tons in 2010 to 10280.5 th. tons in 2017 [14]. The increase in milk production occurred only in agricultural enterprises due to the growth of cow productivity from $3975 \mathrm{~kg}$ in 2010 to $6025 \mathrm{~kg}$ in 2017. Therefore, the main problem of breeding work is the insufficient share of cows of active part in the populations of all native breeds, which is significantly complicates the restoration of breeding system and sire testing and leads to an increase in sperm import. The dependence of Ukrainian livestock breeding on imports of breeding resources has become threatening. In dairy cattle breeding share of such import is over $65 \%$, in pig breeding - more than $40 \%$. Therefore, the mandatory preconditions for ensuring the food security of Ukraine should be the further selective improvement of the native dairy cattle.

M.V.Zubets Institute of Animal Breeding and Genetics, NAAS is an originator of 4 dairy (Ukrainian Black-and-White, Red-and-White, Brown, Red) and 4 beef (Ukrainian, Volynian, Polisian, Southern) cattle breeds, which on their productive traits corresponds to the level of European standards and are the main material basis for the animal-breeding products' manufacturing in Ukraine, for constant selection and reproduction according to industry demands on certain market requirements in our state. Now scientists make scientific support of regional livestock development programs, development of systems for the creation and management of commercial herds of dairy and beef cattle, which contributes to solving the global food problem. According to the scientific and methodological guidance of the Institute, in our country the livestock of the native breeds in agricultural enterprises and households is the basis of livestock breeding ( $86 \%$ of dairy and $69 \%$ of beef cattle in breeding herds). Working for a long time on the genetic improvement of the existing and the creation of new specialized breeds, together with a number of other scientific institutions and the Ministry of Agrarian Policy and Food of Ukraine, the Institute plays a prominent role in ensuring the growth of the average cow yield in industrial enterprises of Ukraine up to $6025 \mathrm{~kg}$ (compared with 1991 - higher by $2086 \mathrm{~kg}$ ).

Conducted on the materials of the breeding registry analysis makes it possible to recommend the most expedient ways and directions of dairy cattle breed improvement in Ukraine $[5,12,13]$. The main dairy breeds for the future should remain newly created Ukrainian Black-and-White, Red-andWhite and Red dairy breeds with their mainly intrabreed improvement and limited involvement of the gene pool of the Holstein improving breed. Taking into account the critical number of populations, the genetic improvement of brown breeds should combine the herds of the Ukrainian Brown Dairy, Lebedyn, Brown Carpathian and Swiss breeds, using predominantly improvers of Swiss and Ukrainian Brown dairy breeds and preserving the gene pool (in the limited number of herds) of Lebedyn and Brown Carpathian. Not fully desirable (taking into account the decrease in reproductive ability and productive longevity), but the objective process of expanding replication of Holstein breed should be carried out by the absorbing crossing at the limited population, recognizing the 
inappropriateness and ineffectiveness of the mass importation of pure-bred young animals from North America and Europe.

Certain share in the system of breeding work with dairy cattle in future as well will occupy purebred improvement of double-directed Simmental breed. In recent years, there is found a restoration of the interest of native livestock breeders to the breeding of Jersey dairy cattle breed, which should be aimed at the creation of pure bred herds.

The main means of genetic improvement of dairy cattle of all breeds remains the restoration of the system of sire selection, which will be facilitated by a significant expansion of the controlled population, the formation of a national information database, state financial support for the organization of sire testing on progeny quality $[5,12]$.

However, the existing animal breeding system in Ukraine on the parameters of information collecting, keeping records of animal productivity, management mechanisms and state support is not in line with international standards and practically does not work in full. The continuation of such a state with the unsatisfactory organization of the breeding process threatens the final destruction of native breeding livestock breeding and significant dependence of the country on the importation of breeding resources. The solution for this problem can be found in the framework of national security in livestock products production. The experience of countries with developed livestock breeding sector shows that there is no country where own system for obtaining, estimating and reproduction of breeding genetic resources would be absent. Therefore, it is strategically important to use mainly native breed resources in the production process.

The Institute is involved in the development and implementation of the tasks of the project of the National Academy of Agrarian Sciences of Ukraine "Modern organizational and functional selection system in livestock breeding of Ukraine", which was widely publicly discussed. A new structure of the breeding service with a clear definition of the organizational basis for the management of breeding affairs and the functional responsibilities of its realization subjects is proposed.

It is foreseen to create a centralized national information base of identification, registration, pedigree and productivity of animals, electronic herd books of breeding animals as the basis for evaluating their genetic value. To accomplish these tasks, the State Enterprise "The Main ScientificIndustrial Informative-and- Selection Center in Animal Breeding of M.V.Zubets Institute of Animal Breeding and Genetics" was created.

The Institute performs a considerable amount of work on improving the regulatory and legislative base on effective selection process in Ukraine. Also, in order to meet the national needs in native breed resources, amendments were made to the Law of Ukraine "On the Breeding Affairs in Livestock", the concept

"Program of selection in livestock breeding for the period till 2025", which identified the priority directions and tasks of the breeding business, optimized the interaction of state authorities, public and professional organizations and scientific institutions on their implementation.

The reform of agriculture in the current market conditions requires the development and implementation of innovative high-tech scientific developments in molecular biology, genetics, biotechnology in order to increase the volume of livestock products production and increase its competitiveness, which determines the direction of implementation of the state policy in the field of animal husbandry on improvement of breeding and productive qualities of animals. The selection of biological objects, based directly on the identification of genes and their mutations that determine the direction and extent of the development of a quantitative trait (QTL), contributes to increased profitability by reducing the generation interval and early estimation of breeding value of animals by means of markers (MAS). On marker selection, one makes the selection of parent pairs on set of 
certain genotypes and they get the offspring with certain genetic potential of the basic productivity indicators.

Taking into account the above-mentioned, animal breeding of Ukraine now requires the introduction of new methodological approaches, which are based on the analysis of hereditary information at the level of regulatory or structural parts of genes, based on the use of DNA polymorphism. Scientific and methodological guidance of the process of gradual implementation into the practice of animal-breeding of modern methods of molecular genetics, which are based on molecular-biologic approaches use, is carried out by M.V.Zubets Institute of Animal Breeding and Genetics, NAAS. The main developments of geneticists are aimed at improving the methods of genetic analysis at individual and population levels, and monitoring the cattle herds by different types of genetic markers. Genetic systems for animal testing on 9 loci of quantitative traits, which are involved in the formation of qualitative traits of dairy and beef productivity are created. Based on the results of the research, conducted on 1500 heads of 24 cattle breeds for 9 genes $[2,4,8]$ one proposed complex model genotypes for increasing the protein content of milk for the animals of Ukrainian Black-and-White ( $\left.-\mathrm{Cn}^{A B}{ }_{L G} A B_{G H} L V_{\text {Pit-1 }} A A_{L E P} A A\right)$ and Red-and-White ($\left.{ }_{n} A A_{L G} A A_{G H} L_{P i t-1} A B\right)$ dairy breeds, Simmental breed ( $\left.-C_{n}^{B B}{ }_{L G} B_{G} B^{L L_{L E P} A B}\right)$, for the increase of fat content in milk - for Ukrainian Black-and-White ( $-{ }_{n} A B{ }_{L G} A B_{G H} V_{\text {Pit-1 }} A A_{L E P B B} / A B$ ) and Red-and-White ( $\left.-\mathrm{Cn}^{A} A A_{L G} A B_{G H} L V_{P i t-1} A B\right)$, Simmental breed ( $\left.-C_{n} B B{ }_{L G} B_{G H} L V_{L E P} A A\right)$. The results on the peculiarities of the genetic structure of the cattle population of 5 breeds of beef direction for the CAPN1 530 and TG5 genes [6] were obtained. High (73-89\%) concentration of the allele G associated with the tenderness of beef was found in the populations of Aberdeen-Angus, Charolais, Hereford and Southern Beef. Analysis of animals on combinations of genotypes of thyreoglobulin and calpaine genes showed that $67.8 \%$ of the studied animals had genotypes GG / CC and GG / CT. Animals of alternative AA / TT genotypes were not detected. There were found animals of different breeds, which are carriers of desirable allelic variants of beef productivity genes. In general, $47.8 \%$ of animals carry both of desirable allelic variants $\mathrm{G}$ and $\mathrm{T}$, which indicates tenderness and "marbleness" of meat. The molecular genetic passporting of 204 bulls of the Bank of Animal Genetic Resources [7, 16] was done in accordance with the recommendations of ISAG/FAO. The work on animal testing on gene polymorphism of the main gene of histological compatibility BoLA-DRB3 at the animal populations on the resistance and predisposition to mastitis in the experimental farms of the Institute "Khrystynivske "and "Nyva" is being conducted.

An equally important problem of dairy cattle breeding in Ukraine is the low animal reproduction level at the background of decreasing the number of livestock and increasing its productivity [13]. In 2017 (data from the State Statistics Service of Ukraine), the calves output was 69 heads per 100 cows, which is the result of natural biological antagonism between yield and reproductive ability of cows. Among other factors reducing the reproductive ability, there is an increase of post-partum complications (endometritis, uterine sub-involutions and ovarian dysfunction), which are due to a decrease in the professional level of technicians (operators) of artificial insemination of cows and heifers and zoo-veterinary specialists. Therefore, personnel issues (training, certification and recertification) are key points for the most farms. In the area of these problems, the biotechnology of animal reproduction is an important part of the scientific direction, which is related to the cryopreservation of genetic material in the form of gametes, embryos, nuclei and other cells and molecules, which have morphofunctional information about the biological object. At present, biotechnology, along with nano- and information and communication technologies became at the highest level of achievements of humanity as a result of technological evolution. Such popularity of this research direction is caused by wide range of innovation transformations, which create conditions for the accelerating progressive changes in livestock breeding and at the economy as a whole. In 
leading countries of the world a powerful bioindustry is already operating. In Ukraine, the range of application of biotechnological approaches is much narrower. Their use is still fragmentary. Therefore, the solution of the scientific and practical task of creating the proper conditions for the establishment and functioning of biotechnological methods on a modern scientific basis, their massive proliferation into livestock production, strengthening of the influence of organizational, economic and social factors for the development of the biotechnological industry in general is actual. Native scientists are currently conducting their research within the NAAS program "Creation and use of nano- and biotechnological materials and means at animal-breeding" in the context of technological possibilities with their practical application.

Among modern biotechnological methods of manipulation with gametes of farm animals one of the most promising one today is in vitro fertilization of pre-mature oocytes of cows and piglets outside the body [10, 15]. Successful fertilization of de-conserved oocytes and further development of the embryos after their cultivation are one of the objective criteria for successful cryopreservation of female gametes. Our research has shown that not only the technology of deep freezing and decontamination, but also the quality and stage of the development of gametes before cryopreservation, affect the level of viability of de-conserved gametes. The results of the research and the accumulated experience of extra-fast freezing of cells make it possible to ensure the viability of gametes of cows and pigs at a high biological level without the use of expensive cryobiological equipment.

In recent years, significant achievements were reached in maturation and fertilization of in-vitro gametes, as native, so de-conserved, obtained from antral follicles of farm animals. Technologies for obtaining oocyte-cumulus complexes from ovaries of animals, their storage, cultivation and fertilization outside the body have been developed, which make it possible to receive a much larger number of embryos for both scientific and practical purposes from different types of animals with high genetic potential. At M.V.Zubets Institute of Animal Breeding and Genetics, NAAS the work on the preservation of gene pool of Grey and Whiteheaded Ukrainian cattle breeds is being conducted using the method of obtaining embryos in vivo and their subsequent cryopreservation. As a result, there were laid down to the Bank of Animal Genetic Resources by 30 embryos of these breeds. As well, there was created a cryo-collection of 750 doses of ejaculated sperm and 44 pig eggs of Mirgorodian breed.

A series of experiments on the use of sex semen for the production of embryos of a certain sex (Ltd. Agro-Soyuz) was done. It was found that the level of embryo formation after the use of split on sex sperm was $66.7 \%$ and did not significantly differ from the level when used the traditional semen (69.6\%). Unsuitable on morphological evaluation for transplantation or cryopreservation, embryos were used for genetic confirmation of their sex. Using the PCR-analysis, it was found that all the embryos under investigation were female, which fully confirmed the effectiveness of sperm sorting. Nowadays in Ukraine (M.V.Zubets Institute of Animal Breeding and Genetics, NAAS and O.O.Chuiko Institute of Surface Chemistry, NAS) intensive work on the improvement of biotechnological methods of reproduction of farm animals using nanomaterials is being led. The research is aimed at developing a biotechnological model of use nanobiomaterials in the technology of in vitro formation of swine embryos and a new technology for the conservation and rational utilization of genetic resources of native pig breeds [1,9]. It is based on application in sperm and egg cells cryopreservation and defrosting mediums, layered on a highly dispersed silica molecule of various variants of biologically active substances (cattle blood serum albumin, $\mathrm{N}$-acetylneuramic acid), which, at a concentration of $0.001 \%$, increase the initial activity of de-conserved ejaculated boar spermatozoa by $13.3 \%$, and at $0.1 \%$ concentration ensure $20.2 \%$ more formed matured in vitro eggs. 
The addition of $\mathrm{N}$-galactosamine at $0.001 \%$ concentration increased the activity of bovine spermatozoa by $11.6 \%$, and the level of pig embryo formation at such concentration reaches $33.3 \%$ (21 embryos out of 63 inseminated eggs).

On the results of work developed:

- Technological instruction of synthesis of new biologically active nanomaterials at the base of highly dispersed silica and biomolecules.

- Methodical recommendations for the use of new biologically active nanomaterials as the main components of improved cryomedia.

- Technological regulation of pig autochthonous breeds genetic resources cryopreservation and their cryocollection.

- Recommendations on rules and principles for the formation of gene pool bank.

- Recommendations for optimized technology for autochthonous pigs' sperm and eggs cryoconservation with the use of nanomaterials.

Organizational measures in dairy cattle breeding arise as separate issues in the context of approaching the EU requirements. Most large farms and agricultural enterprises will be able effectively adapt the production requirements during short period of time. The possible decrease in production will be because of small agricultural enterprises and households, that will lead to a reduction in the number of livestock and a shortage of raw material for the dairy industry. The negative effect of a ban on the sale of low quality milk will be substantial. The share of milk produced by this category of farms in 2017 amounts to 7719.6 thousand tons, which is $75.1 \%$ of the total milk production in Ukraine.

An urgent problem is the preservation of the gene pool of autochthonous native dairy breeds due to their non-competitiveness with specialized dairy breeds. Solving this problem requires a scientific substantiation of the expediency of breeding such animals in order to prevent the elimination the whole number of genes and gene complexes that determine the valuable inherited animal qualities.

To monitor and preserve the diversity of genetic resources of farm animals in Ukraine, they carry out a set of works on the scientific program of the NAAS "System of work in populations and conservation of biological diversity of genetic resources of farm animals" (Conservation of gene pool of breeds). 13 scientific institutions coordinated by the main institution, NMC - M.V.Zubets Institute of Animal Breeding and Genetics are involved in the implementation of fundamental and applied tasks in this field. On the results of the conducted research the "Program for the conservation of the gene pool of local and endangered breeds of farm animals in Ukraine for 2017-2025" [11] was developed. It summarizes the methodological grounds for the preserving the gene pool, classifies animal breeds in accordance with the criteria of risk, justifies the minimum sizes of herds (real and virtual) of endangered species, defines the minimum amount of subsidies for the full functioning of small breeds, specifies general methodological approaches to the assessment of the specifics of genetic resources and highlights a complex of selection, genetic, biotechnological, organizational and financial and economic measures aimed at the preservation of the gene pool of local and endangered species of farm animals in Ukraine $[11,17,18]$.

\section{Conclusions}

The scientific developments of M.V.Zubets Institute of Animal Breeding and Genetics, NAAS are aimed at solving theoretical, methodological, organizational and technological, informational and analytical issues, creating a legal and regulatory framework for the implementation of modern selection-genetic methods into the practice of native livestock breeding, and the transition of the branch into a qualitatively new level in accordance with European standards. This requires an appropriate level of funding, modernization of the system of zootechnical accounting, the creation of program packages for the identification of promising selection objects and the optimal selection of 
pairs according to yearly evaluation results and genetic analysis, development for all genetic control laboratories of the fixed system of methodics standardization, determination of genotypes of animals by genes of quantitative traits, their identification by microsatellite loci, the identification of the most valuable breeding individuals for further reproduction by indicators of optimum genetic compatibility.

According to the breed structure, breeding dairy and beef cattle now and in the future should be represented by animals of native breeds with their predominantly intrabreed improvement. The main means of genetic improvement of dairy cattle of all breeds remains the restoration of the system of sire selection, which will be facilitated with significant expansion of the controlled livestock, the formation of a nationwide information database, state financial support for the organizing progeny sire testing.

Scientific and methodological guidance and coordination of scientific research on the development and implementation of breeding programs for the creation of new, qualitative improvement and preservation of the gene pool of existing breeds and types of farm animals with widespread use of modern achievements in the field of genetics and biotechnology is carried out by M.V.Zubets Institute of Animal Breeding and Genetics, NAAS.

\section{Bibliography}

1. Shcherbak O.V., Ziuziun A.B., Osypchuk O.S. et al. (2017). Vyvchennia biolohichnoi aktyvnosti nanomaterialu $v$ umovakh kultyvuvannia spermatozoidiv ta ootsytiv svynei in vitro. Faktory eksperymentalnoi evoliutsii orhanizmiv. [Study of biological activity of nanomaterial in cultivating sperm and oocytes of pigs in vitro. Factors of experimental evolution of an organism]. Kyiv: Loho. T. 20. P. $256-260$. [In Ukrainian].

2. Kopylov K.V., Biriukova O.D., Berezovskyi O.V., Basovskyi D.M. (2015). Henetychnyi monitorynh $v$ stadi ukrainskoi chervono-riaboi molochnoi porody za kompleksom heniv. [Genetic monitoring in a herd of Ukrainian red-breasted breed for a complex of genes]. Tekhnolohiia vyrobnytstva i pererobky produktsii tvarynnytstva. Bila Tserkva. Vyp. 1 (116). P. 28 - 31. [In Ukrainian].

3. Derzhavnyi reiestr subiektiv pleminnoi spravy u tvarynnytstvi. [State register of subjects of tribal affairs in animal husbandry]. URL: http://www.animalbreedingcenter.org.ua/derjplemreestr [In Ukrainian].

4. Berezovskyi O.V., Polupan Yu.P., Ruban S.Iu., Kopylov K.V. (2015). Zviazok polimorfizmu za henamy -CN, TG5, LEP z molochnoiu produktyvnistiu koriv ukrainskykh molochnykh porid. [The connection of polymorphism to the -CN, TG5, LEP genes with the milk productivity of Ukrainian dairy cows]. Rozvedennia i henetyka tvaryn. Kyiv. Vyp.49. P. 154 - 164. [In Ukrainian].

5. Zubets M.V., Bashchenko M.I., Polupan Yu.P. (2012). Porodna struktura i perspektyvy selektsii molochnoi khudoby. [The breed structure and prospects of breeding of dairy cattle]. Visnyk ahrarnoi nauky. No 10. P. 34 - 38. [In Ukrainian].

6. Metlytska O.I., Kopylov K.V., Berezovskyi O.V. (2016). Suchasni molekuliarno-henetychni pidkhody dlia pidvyshchennia efektyvnosti selektsiinoho protsesu $v$ tvarynnytstvi Ukrainy. [Modern molecular genetic approaches for increasing the efficiency of the breeding process in animal husbandry in Ukraine]. Rozvedennia i henetyka tvaryn. Vinnytsia. Vyp.51. P. 193 - 200. [In Ukrainian].

7. Kopylov K.V., Zhukorskyi O.M., Kopylova K.V. et al. (2014). Metodolohiia otsinky henotypu tvaryn za molekuliarno-henetychnymy markeramy $v$ tvarynnytstvi Ukrainy. [Methodology for assessing the genotype of animals by molecular genetic markers in livestock production in Ukraine]. ; za red. M.V. Hladiia. Kyiv: Ahrarna nauka, 212 p. [In Ukrainian].

8. Kopylov K.V., Metlytska O.I., Mokhnachova N.B., Suprovych T.M. (2016). Molekuliarnohenetychnyi monitorynh $v$ systemi zberezhennia henetychnykh resursiv tvaryn. [Molecular-genetic 
monitoring in the system of conservation of genetic resources of animals]. Visnyk ahrarnoi nauky. No 6. P. 43 - 47. [In Ukrainian].

9. Kovtun S., Galagan N., Shcherbak O., Klimenko N. (2015). Nanokompozity na osnove visokodispersnogo kremnezema dlya optimizatsii tekhnologi dlitel'nogo sokhraneniya genofonda sel'skokhozyaystvennykh zhivotnykh. [Nanocomposites on the basis of high silica for optimizing the long-term conservation of the gene pool of farm animals]. Science and Education in the Modern World: proceedings of the of the 4th International academic congress (New Zealand, Auckland, 5 - 7 January 2015). Auckland: Auckland University Press, V. II. P. 969 - 973. [In Russian].

10. Kovtun S.I., Zyuzyun A.B., Shcherbak O.V. et al. (2016). Poluchenie in vitro i kriokonservatsiya embrionov krupnogo rogatogo skota opredelennogo pola. [Receiving in vitro and cryopreservation of cattle embryos of a certain sex]. Collection of works scientific symposium with international participation dedicated to 60th anniversary of the founding of the Institute «Zootechnycal science an important factor for the European type of agriculture» (Scientifical and practical institutute of biotechnologies in animal husbandry and veterinary medicine). Maximovca, Moldova. P. $485-489$. [In Russian].

11. Hladii M.V., Polupan Yu.P., Basovskyi D.M. et al. (2018). Prohrama zberezhennia henofondu lokalnykh i znykaiuchykh porid silskohospodarskykh tvaryn v Ukraini na 2017 - 2025 roky. [Програма збереження генофонду локальних і зникаючих порід сільськогосподарських тварин в Україні на 2017 - 2025 роки]. Sumy. 85 р. [In Ukrainian].

12. Bashchenko M.I., Polupan Yu.P., Ruban S.Iu., Bazyshyna I.V. (2012). Stan i perspektyvy poridnoho udoskonalennia molochnoho skotarstva i vidnovlennia systemy selektsii buhaiv. [Status and prospects of breed improvement of dairy cattle breeding and restoration of the system of cattle breeding]. Rozvedennia i henetyka tvaryn. Kyiv, Vyp. 46. P. 79 - 83. [In Ukrainian].

13. Bashchenko M.I., Hladii M.V., Melnyk Yu.F. et al. (2017). Stan i perspektyvy rozvytku molochnoho skotarstva Ukrainy. [Status and prospects of dairy cattle breeding in Ukraine]. Rozvedennia i henetyka tvaryn. Kyiv, Vyp. 54. P. 6 - 14. [In Ukrainian].

14. Tvarynnytstvo. [Livestock breeding]. (1990 - 2017). URL: http://www.ukrstat.gov.ua [In Ukrainian].

15. Shcherbak O.V., Zyuzyun A.B., Kovtun S.I. (2017). Kriokonservatsiya embrionov kak metod sokhraneniya genofonda belogolovoy ukrainskoy porody krupnogo rogatogo skota. [Cryoconservation of embryos as a method of preserving the gene pool of white-headed cattle of the bald breed]. Molochnoe i myasnoe skotovodstvo. No 2. P. 21 - 23. [In Russian].

16. Shelov A.V., Kopylov K.V., Kramarenko S.S., Kramarenko O.S. (2017). Analysis of populationgenetic processes in different cattle breeds by microsatellite loci of DNA. Agricultural Science and Practice. V. 1. P. $74-78$.

17. Polupan Yu., Kovtun S., Kuzebniy S., Rieznykova N. (2018). Farm animal biodiversity in Ukraine and its loss. The 4th International Symposium on EuroAsian Biodiversity (SEAB2018, $03-06$ July 2018, Kiev, Ukraine): Abstract eBook. Kyiv, P. 93.

18. Polupan Yu., Bashchenko M., Rieznykova N., Priyma S. (2018). Genetic resources of dairy and beef cattle breeding in Ukraine. Zhivotnovodstvo - traditsii, biologichno raznoobrazie i spode len opit [Livestock - Traditions, Biodiversity and Shared Experience]: sbornik rezyume Mezhdunarodna nauchna konferentsiya po zhivotnovodstvo (27 april 2018, Sliven). Sofiya: Avangard Prima, P. 32 33. [In Russian]. 